Egyptian Journal of Aquatic Biology \& Fisheries

Zoology Department, Faculty of Science,

Ain Shams University, Cairo, Egypt.

ISSN $1110-6131$

Vol. 24(3): 365 - 379 (2020)

www.ejabf.journals.ekb.eg

\title{
Morphological study of Sudanonautes africanus (Miline-Edwards, 1869) in three freshwater bodies of Ondo State, Nigeria.
}

\section{Omoniyi M. Popoola * and Faith E. Udoh}

Department of Fisheries and Aquaculture Technology, Federal University of Technology, Akure, Nigeria.

"Corresponding Author: ompopoola@futa.edu.ng

\begin{abstract}
ARTICLE INFO
Article History:

Received: Nov. 30, 2019

Accepted: April 28, 2020

Online: May 2020
\end{abstract}

Keywords:

Decapod,

crabs,

Sudanonautes africanus,

Morphology,

Ondo State,

Canonical Variate

\begin{abstract}
Freshwater crabs are a cheap and important source of animal protein for human beings. They also serve as bio-indicators of ecosystem disruption and also conservation icons. Despite their importance, there are still some unresolved issues in their phylogenies. This study aimed to examine the morphological variations in freshwater crab, $S$. africanus from three different water bodies in South-west, Nigeria. Thirty samples were collected from each of the study locations morphological study using morphometrics and meristics characters. Morphometrics characters did not show variations in species of crabs, unlike meristic that showed variations in the episternum and abdominal segments of $S$. africanus. The study also revealed that the crabs exhibit a negative allometric growth $(b<3)$. The condition factor revealed that the crabs are healthy $(K>1)$. Cluster diagram of the Canonical Variate analyses of the morphological parameters showed that there are no variations in the morphological characteristics of $S$. africanus. Cluster diagram of the meristic characters shows that there are little variations in the meristic characters of $S$. africanus in the three study locations.
\end{abstract}

\section{INTRODUCTION}

Crabs are decapod crustaceans with stout and strong legs with which they move around for food and escape from predator. Their body is generally covered with a thick exoskeleton composed primarily of chitin and calcium carbonate. They are of different sizes and show sexual dimorphism on their external morphology. Their general body is divided to head, thorax and pleon with the head and thorax (cephalothorax) covered by a broad carapace. Freshwater crabs are found in large number in nearly all the available freshwater bodies in Nigeria, but they are underutilized except for local consumption (Sodamola et al., 2010). However, Sudanonautes africanus is restricted to the more humid areas of the coastal rainforest belt from south-east Nigeria. They are found in a range of permanent aquatic habitats from large rivers and small streams (with both fast and slow flowing water) to ponds. The species of crabs is capable of breathing air and is often found on land at night. This crab also occurs in temporary water sources such as drainage culverts and ditches (Cumberlidge et al., 2009). Adult males and females of $S$. africanus do not co-habit in a single hole. The burrows dug by adult males are usually further away from the water than those of adult females and sub-adults of both sexes (Mvogo-Ndongo et al., 2017). 
A lot of interests have been developed in the study of decapods because of their morphological diversities and economic importance. Since the development of this keen interest in the study of decapods, there have not been clear classifications of members of the phylum because of their morphological diversity (Chu et al., 2002). This has hindered their phylogenetic study. According to Chu et al. (2002), morphological cladistics analysis has provided some insights to the phylogeny of crustaceans but many key issues have been left unsettled, especially their relationships.

The morphology of decapod crustaceans shows a large diversity concerning the overall body shape and structure of the appendages. Morphological characters such as morphometrics and meristic have been widely used to identify fish population (Turan, 2004; Turan et al., 2004). Morphometric studies of crabs have been widely accepted in population biology studies - used to trace the historical development (ontogeny), describe the growth patterns and measure the sequence of changes that occur during the evolution of fresh water crabs while modifying the description of old characters (Elewa and Ashraf, 2004). It is also being used as an important index in molecular studies as well as in population ecology. Information on the morphometric analyses can be a necessary tool for the assessment of the fishery of fresh water crabs. This is to ensure the sustainability and also form the basis for their molecular and biochemical studies. Such knowledge can be useful for further studies on the life history, taxonomy of the species and in the development of its fishery resource management and culture.

This study is devoted to observe the morphological variations in S. africanus in three freshwater bodies in Ondo state of Nigeria. In order to achieve this the proxy of morphometric and meristic characters were used to measure the genetic variation of $S$. africanus in the three populations.

\section{MATERIALS AND METHODS}

\subsection{The study area}

This study was carried out in three rivers (Ala, Ogbese and Owena rivers respectively) in Ondo state, South-west, Nigeria. Sample collections were carried out on each of the study locations (Figure 1). River Ala ( $\left.7^{\circ} 263 \mathrm{~N}, 5^{\circ} 205 \mathrm{E}\right)$ is located in Akure, the capital of Ondo state of Nigeria. River Ogbese $\left(7^{\circ} 261 \mathrm{~N}, 5^{\circ} 378 \mathrm{E}\right)$ is located at Ogbese village (near Akure) South western Nigeria. It has it source from Aaye-Ekiti in Ekiti state and flows through Ogbese town in Akure North local government (Oyewole et al., 2013). River Owena ( $\left.7^{\circ} 399 \mathrm{~N}, 5^{\circ} 896 \mathrm{E}\right)$ is located along the AkureIlesha road.

\subsection{Sample collection}

Thirty (30) samples of freshwater crabs were collected from each of the study locations (Ala, Ogbese and Owena Rivers respectively) between July and October 2016. The live specimens were either hand- picked, collected from baited traps, pulled out of their holes, or collected from farmers who caught them on their farmlands. The collected samples were placed in an ice chest before they were transported to the Fisheries and Aquaculture Technology laboratory, Department of Fisheries and Aquaculture Technology, Federal University of Technology, Akure (FUTA) for preservation and further analysis. 


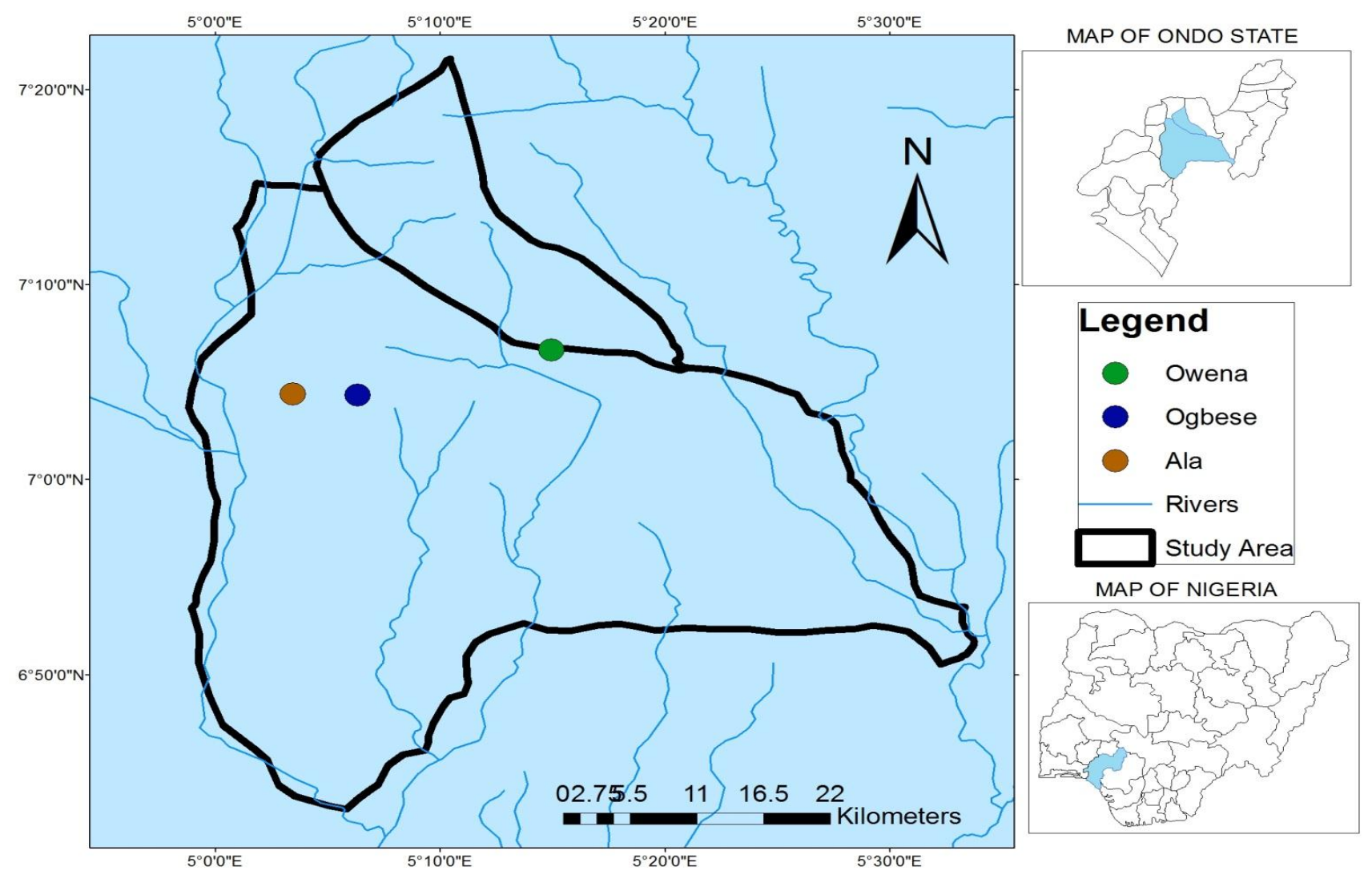

Figure 1: A map of the study locations

\subsection{Morphometric Studies of S. africanus}

The collected specimens were sexed based on the method described by Bello-olusoji et al. (2009). The total body weight of the crab was measured using a sensitive scale (OPTIMA OPD-E). A pair of dividers was used to carry out the morphometric measurements (to the nearest millimeter) of the samples by placing it at the ends of the parameters to be measured. The parameters that were considered are the Body weight (BW) Carapace width (CW), Carapace length (CL), Length of left chelae (LLC), Length of right chelae (LRC), Width of left chelae (WLC), Width of right chelae (WRC), Mandibular palp, Front width (FW), Abdominal Length (AL), Length of dactyl (LD), Length of palm (LP), and Width of Palm (WP).

\subsection{Meristic studies of $S$. africanus}

The meristic characters such as the abdominal segment (this was done by turning the ventral part of the cephalothorax (i.e the thoracic sternum), a magnifying lens (hand lens) was used to count the number of teeth on each of the chela of the crab. The meristic characters considered were recorded and these include sternum (ST), number of Episternite (EST), Abdominal segment (AS), Thoracic sternite (TS) (was counted by opening the abdomen of the crab), Number of teeth on left chelae (NTL), and Number of teeth on right chelae (NTR). 


\subsection{Data analysis on Morphometric studies of S. africanus}

Data on the morphometric and meristic characters were recorded and subjected to analysis using the PAST 3.0 software. The dimensionality of the data was reduced by using Principal component Analysis (PCA). The mean and standard deviations of the freshwater crab population was determined using Microsoft Office Excel in PC window (2007).

The Length-weight relationship was estimated using the equation $\mathrm{W}=\mathrm{aL}^{\mathrm{b}}$ (Bagenal and Tesch, 1978) Where $\mathrm{W}$ is the weight of the crab, $a$ is the intercept, $\mathrm{L}$ is the carapace length and $b$ is the slope or known as growth constant. The values of $a$ and $b$ was computed from the log transformed values of the length and weight, i.e.

$\log \mathrm{W}=\log \mathrm{a}+\mathrm{b} \log \mathrm{CL}$

Where $\mathrm{W}=$ weight $(\mathrm{g})$ of the crabs, $\mathrm{CL}=$ horizontal carapace length (using the linear regression routine of Microsoft Office Excel in PC windows (2007). The parameters $a$ (intercept) and $b$ (slope) was estimated by linear regression based on logarithms; $\log (\mathrm{W})=\log (\mathrm{a})+\mathrm{b} \log (\mathrm{L})$. An equation expressing the carapace width/length-weight relationship of $S$. africanus was calculated in relation to the study location.

The condition factor, $\mathrm{K}$ was also calculated to determine the state of well-being of the crabs in the three study locations. The formula for the condition factor is expressed thus:

$$
\mathrm{K}=\frac{100 \mathrm{~W}}{\mathrm{~L}^{3}}
$$

(Gayanilo and Pauly, 1997)

Where $\mathrm{K}=\mathrm{Co}$

ndition factor, $\mathrm{W}=$ Weight of crab, $\mathrm{L}=$ Horizontal carapace length of crab. The bias due to size and age on the morphometric and meristic data set was reduced using method desribed by Elliott $\boldsymbol{e t} \boldsymbol{a l}$. (1995) with little modification.

\section{RESULTS}

\subsection{Morphometric parameters of male Sudanonautes africanus}

Table 1 shows the mean and standard deviations of the morphometric characters of male S. africanus from the three locations (Ala, Ogbese and Owena Rivers). The body weights (BW) of the studied species of crab were $67.07 \pm 26.92 \mathrm{~g}, 69.07 \pm 25.57 \mathrm{~g}$ and $68.33 \pm 27.59 \mathrm{~g}$ and the carapace lengths $(\mathrm{CL})$ were $5.88 \pm 1.36 \mathrm{~cm}, 5.50 \pm 1.24 \mathrm{~cm}$, and $5.80 \pm 1.10 \mathrm{~cm}$ for Ala, Ogbese and Owena Rivers respectively. The mean of the carapace width of the male $S$. africanus shows $5.95 \pm 1.33 \mathrm{~cm}, 5.84 \pm 0.87 \mathrm{~cm}$, $6.03 \pm 1.26 \mathrm{~cm}$ for the three study locations. The morphometric characters of the male $S$. africanus showed no significant differences $(\mathrm{P}>0.05)$ among the three study locations.

\subsection{Morphological parameters of female Sudanonautes africanus}

mean and standard deviations among the three locations (Ala, Ogbese and Owena Rivers). The body weights (BW) of the studied species of crab were $59.05 \pm 20.95 \mathrm{~g}, 55.00 \pm 15.45 \mathrm{~g}$ and $60.27 \pm 20.31 \mathrm{~g}$ for Ala, Ogbese and Owena Rivers respectively. The total carapace lengths (CL) were $5.62 \pm 1.39 \mathrm{~cm}$, $55.07 \pm 0.91 \mathrm{~cm}$, and $5.45 \pm 1.33 \mathrm{~cm}$ for Ala, Ogbese and Owena Rivers respectively. The mean of the 
carapace width of the male $S$. africanus shows $6.16 \pm 0.75 \mathrm{~cm}, 5.78 \pm 1.08 \mathrm{~cm}, 5.66 \pm 0.84 \mathrm{~cm}$ for the three study locations. The morphological characters of $S$. africanus showed that there is no significant difference $(\mathrm{P}>0.05)$ among the three study locations considering the male animals. However, there were significant differences $(\mathrm{P}<0.05)$ between the Mandibular palp (MP) of female S. africanus collected from Ala and Ogbese Rivers. The results of the other parameters are presented in Table 1. From the results, female $S$. africanus do not vary from each other in the three study locations

Table 1: Morphometric parameters of Male S. africanus obtained from the three study locations (n=90).

\begin{tabular}{|c|c|c|c|c|c|c|}
\hline \multirow{3}{*}{ Parameter } & \multicolumn{2}{|c|}{ ALA RIVER } & \multicolumn{2}{|c|}{ OGBESE RIVER } & \multicolumn{2}{|c|}{ OWENA RIVER } \\
\hline & $\mathrm{Mr}+\mathrm{CD}$ & Female & Male & Female & Male & Female \\
\hline & 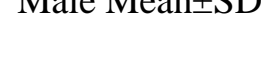 & Mean \pm SD & Mean \pm SD & Mean \pm SD & Mean \pm SD & Mean \pm SD \\
\hline $\mathrm{BW}$ & $67.07 \pm 26.92^{\mathrm{a}}$ & $59.05 \pm 20.95^{\mathrm{a}}$ & $69.07 \pm 25.57^{\mathrm{a}}$ & $55.00 \pm 15.45^{\mathrm{a}}$ & $68.33 \pm 27.59^{\mathrm{a}}$ & $60.27 \pm 20.31^{a}$ \\
\hline $\mathrm{CL}$ & $5.88 \pm 1.36^{\mathrm{a}}$ & $5.62 \pm 1.39^{\mathrm{a}}$ & $5.50 \pm 1.24^{\mathrm{a}}$ & $5.07 \pm 0.91^{\mathrm{a}}$ & $5.80 \pm 1.10^{\mathrm{a}}$ & $5.45 \pm 1.33^{\mathrm{a}}$ \\
\hline $\mathrm{CW}$ & $5.95 \pm 1.33^{\mathrm{a}}$ & $6.16 \pm 0.75^{\mathrm{a}}$ & $5.84 \pm 0.87^{\mathrm{a}}$ & $5.78 \pm 1.08^{\mathrm{a}}$ & $6.03 \pm 1.26^{\mathrm{a}}$ & $5.66 \pm 0.84^{\mathrm{a}}$ \\
\hline LLC & $7.09 \pm 1.54^{\mathrm{a}}$ & $7.26 \pm 0.96^{\mathrm{a}}$ & $7.68 \pm 1.82^{\mathrm{a}}$ & $6.47 \pm 1.04^{\mathrm{a}}$ & $7.89 \pm 2.03^{\mathrm{a}}$ & $6.77 \pm 1.50^{\mathrm{a}}$ \\
\hline LRC & $7.82 \pm 1.66^{\mathrm{a}}$ & $7.67 \pm 1.16^{\mathrm{a}}$ & $7.87 \pm 1.46^{\mathrm{a}}$ & $7.05 \pm 0.85^{\mathrm{a}}$ & $8.35 \pm 2.32^{\mathrm{a}}$ & $7.67 \pm 1.49^{\mathrm{a}}$ \\
\hline WLC & $1.43 \pm 0.44^{\mathrm{a}}$ & $1.43 \pm 0.37^{\mathrm{a}}$ & $2.05 \pm 1.43^{\mathrm{a}}$ & $1.50 \pm 0.70^{\mathrm{a}}$ & $1.57 \pm 0.39^{\mathrm{a}}$ & $1.58 \pm 0.39^{\mathrm{a}}$ \\
\hline WRC & $1.90 \pm 0.46^{\mathrm{a}}$ & $1.75 \pm 0.41^{\mathrm{a}}$ & $2.52 \pm 1.44^{\mathrm{a}}$ & $1.90 \pm 1.02^{\mathrm{a}}$ & $2.02 \pm 0.48^{\mathrm{a}}$ & $1.83 \pm 0.30^{\mathrm{a}}$ \\
\hline MP & $1.51 \pm 0.29^{\mathrm{a}}$ & $1.65 \pm 0.26^{\mathrm{b}}$ & $1.56 \pm 0.39^{\mathrm{a}}$ & $1.45 \pm 0.25^{\mathrm{a}}$ & $1.57 \pm 0.32^{\mathrm{a}}$ & $1.51 \pm 0.21^{\mathrm{ab}}$ \\
\hline FW & $1.47 \pm 0.26^{\mathrm{a}}$ & $1.57 \pm 0.31^{\mathrm{a}}$ & $1.53 \pm 0.28^{\mathrm{a}}$ & $1.55 \pm 0.29^{\mathrm{a}}$ & $1.62 \pm 0.24^{\mathrm{a}}$ & $1.43 \pm 0.19^{\mathrm{a}}$ \\
\hline $\mathrm{AL}$ & $4.23 \pm 0.96^{\mathrm{a}}$ & $4.11 \pm 0.86^{\mathrm{a}}$ & $3.89 \pm 0.55^{\mathrm{a}}$ & $3.95 \pm 0.47^{\mathrm{a}}$ & $4.27 \pm 0.71^{\mathrm{a}}$ & $4.01 \pm 0.87^{\mathrm{a}}$ \\
\hline AW & $3.77 \pm 0.50^{\mathrm{a}}$ & $4.00 \pm 0.42^{\mathrm{a}}$ & $3.86 \pm 0.43^{\mathrm{a}}$ & $3.93 \pm 0.73^{\mathrm{a}}$ & $3.97 \pm 0.44^{\mathrm{a}}$ & $3.78 \pm 0.48^{\mathrm{a}}$ \\
\hline LD & $2.71 \pm 1.04^{\mathrm{a}}$ & $2.37 \pm 0.48^{\mathrm{a}}$ & $3.34 \pm 1.31^{\mathrm{a}}$ & $2.30 \pm 0.80^{\mathrm{a}}$ & $2.56 \pm 0.70^{\mathrm{a}}$ & $2.66 \pm 1.09^{\mathrm{a}}$ \\
\hline LP & $2.39 \pm 0.86^{\mathrm{a}}$ & $2.23 \pm 0.93^{\mathrm{a}}$ & $2.16 \pm 0.62^{\mathrm{a}}$ & $2.05 \pm 1.01^{\mathrm{a}}$ & $2.01 \pm 0.62^{\mathrm{a}}$ & $2.01 \pm 0.49^{\mathrm{a}}$ \\
\hline WP & $2.11 \pm 0.77^{\mathrm{a}}$ & $1.83 \pm 0.44^{\mathrm{a}}$ & $1.93 \pm 0.37^{\mathrm{a}}$ & $1.57 \pm 0.42^{\mathrm{a}}$ & $1.97 \pm 0.52^{\mathrm{a}}$ & $1.71 \pm 0.37^{\mathrm{a}}$ \\
\hline
\end{tabular}

$\mathrm{BW}=$ Body weight, $\mathrm{CW}=$ Carapace width, $\mathrm{CL}=$ Carapace length, $\mathrm{LLC}=$ Length of Left chela, $\mathrm{LRC}=$ Length of right chela, WLC $=$ Width of left chela, WRC $=$ Width of right chela, MP $=$ Length of Mandibular palp, FW= Frontal width, $\mathrm{AL}=$ Abdominal length, $\mathrm{AW}=$ Abdominal width, $\mathrm{LD}=$ Length of dactyl, $\mathrm{LP}=$ Length of palm, $\mathrm{WP}=$ Width of palm. 
Table 2: Meristic parameters of male S. africanus obtained from the three study locations $(\mathrm{n}=90)$

\begin{tabular}{|c|c|c|c|c|c|c|}
\hline \multirow{3}{*}{ Parameter } & \multicolumn{2}{|l|}{ ALA RIVER } & \multicolumn{2}{|l|}{ OGBESE RIVER } & \multicolumn{2}{|l|}{ OWENA RIVER } \\
\hline & Male & Female & Male & Female & Male & Female \\
\hline & Mean \pm SD & Mean \pm SD & Mean \pm SD & Mean \pm SD & Mean \pm SD & Mean \pm SD \\
\hline ST & $6.13 \pm 0.52^{\mathrm{a}}$ & $5.67 \pm 0.62^{a}$ & $6.13 \pm 0.64^{\mathrm{a}}$ & $6.20 \pm 0.68^{a}$ & $6.00 \pm 0.53^{\mathrm{a}}$ & $5.27 \pm 2.22^{\mathrm{a}}$ \\
\hline EST & $3.13 \pm 0.52^{\mathrm{a}}$ & $3.60 \pm 0.83^{\mathrm{a}}$ & $4.87 \pm 1.88^{\mathrm{b}}$ & $4.20 \pm 1.78^{\mathrm{a}}$ & $3.53 \pm 1.13^{\mathrm{a}}$ & $3.33 \pm 1.54^{\mathrm{a}}$ \\
\hline TS & $6.27 \pm 0.59^{\mathrm{a}}$ & $6.00 \pm 0.53^{a}$ & $6.33 \pm 1.18^{\mathrm{a}}$ & $6.20 \pm 0.56^{\mathrm{a}}$ & $6.27 \pm 0.46^{\mathrm{a}}$ & $6.00 \pm 0.00^{\mathrm{a}}$ \\
\hline AS & $6.47 \pm 0.64^{\mathrm{ab}}$ & $6.20 \pm 0.68^{a}$ & $6.73 \pm 0.46^{\mathrm{b}}$ & $6.33 \pm 0.62^{\mathrm{a}}$ & $6.27 \pm 0.46^{\mathrm{a}}$ & $6.00 \pm 0.00^{\mathrm{a}}$ \\
\hline NTL & $15.07 \pm 7.21^{\mathrm{a}}$ & $11.13 \pm 5.05^{\mathrm{a}}$ & $10.47 \pm 4.53^{\mathrm{a}}$ & $8.07 \pm 2.49^{\mathrm{a}}$ & $12.40 \pm 8.53^{\mathrm{a}}$ & $10.33 \pm 6.54^{\mathrm{a}}$ \\
\hline NTR & $14.20 \pm 7.66^{\mathrm{a}}$ & $13.40 \pm 5.90^{\mathrm{a}}$ & $12.53 \pm 4.42^{\mathrm{a}}$ & $11.87 \pm 3.04^{\mathrm{a}}$ & $14.93 \pm 8.68^{\mathrm{a}}$ & $12.07 \pm 8.81^{\mathrm{a}}$ \\
\hline
\end{tabular}

\subsection{Meristic parameter of male S. africanus}

The mean and standard deviations of the meristic characters of $S$. africanus in the three study locations are presented in Table 2. From the result it was observed that significant differences (P $>0.05$ ) exist in some of the meristic characters of $S$. africanus. The Episternite (EST) of the crab from Ogbese River was significantly different $(\mathrm{P}<0.05)$ from the other two locations. Also, there were significant differences $(\mathrm{P}<0.05)$ between the Abdominal Segment (AS) of male $S$. africanus collected from Ogbese and Owena River. There was no significant difference $(\mathrm{P}>0.05)$ between the abdominal segment of male $S$. africanus collected from Ala River and the other two study locations.

Table 2: Meristic parameters of male S. africanus obtained from the three study locations $(\mathrm{n}=90)$ $\mathrm{ST}=$ Number of sternum, EST $=$ Number of Episternite, $\mathrm{TS}=$ Number of Thoracic segment, AS= Number of abdominal segment, NTL= Number of teeth on the left chela, NTR= Number of teeth on the right chela.

\subsection{Length-weight relationship of $S$. africanus}

The relationship between the Carapace length (CL) and Body weight (BW) of each of S. africanus in the three study locations are presented in table 3 . The result of the condition factor of S. africanus in the three study locations show that the crabs are healthy and they all have a negative allometric growth $(b<3)$. From the Table, the S. africanus in Ogbese River is healthier $(\mathrm{K}=41.99)$ than the crabs in the other two study locations. The strength of the relationship between the carapace length and body weight of $S$. africanus is determined by the correlation coefficient. From the study, the $S$. africanus in the Owena exhibit strongest relationship (0.55) in between the Carapace length and Body weights.

Table 3: Relationship between Body weights (WT), Carapace Length (CL) and condition factor of S. africanus in the study locations 


\begin{tabular}{lccccccccc}
\hline \multicolumn{10}{c}{ Growth parameters } \\
\hline RIVER & $\mathrm{n}$ & $a$ & $b$ & $\mathrm{n}$ & $a$ & $b$ & $K$ & $\mathrm{R}^{2}$ & Growth Pattern \\
ALA & 15 & 0.11 & 0.62 & 30 & 2.18 & 1.1 & 33.17 & 0.41 & Allometric \\
OGBESE & 15 & 0.2 & 0.4 & 30 & 2.72 & 0.83 & 41.99 & 0.31 & Allometric \\
OWENA & 15 & 4.12 & 0.05 & 30 & 1.83 & 1.33 & 36.1 & 0.55 & Allometric \\
\hline
\end{tabular}

Where $\mathrm{a}=$ Intercept, $\mathrm{b}=$ Growth pattern, $\mathrm{R}^{2}=$ Correlation coefficient, and $\mathrm{K}=$ Condition factor

\section{Principal component loading analysis of the Morphological parameters of $S$. africanus}

To know the characters that contribute to the variation observed in S. africanus the loading plots was done on the Principal component 1 (PC 1). From the loadings in Figure 3, Length of Right Chelae (LRC), the Length of left chelae (LLC), Carapace Length (CL), Carapace width (CW) and the Abdominal Length (AL) have Eigen values above 0.25. Also, Number of teeth on the left chela (NTL) and Number of teeth on the right chela (NTR) (figure 4) are meristic characters that contributed to the variation observed in $S$. africanus. These characters have contributed more to the morphological variations of $S$. africanus in the study locations.

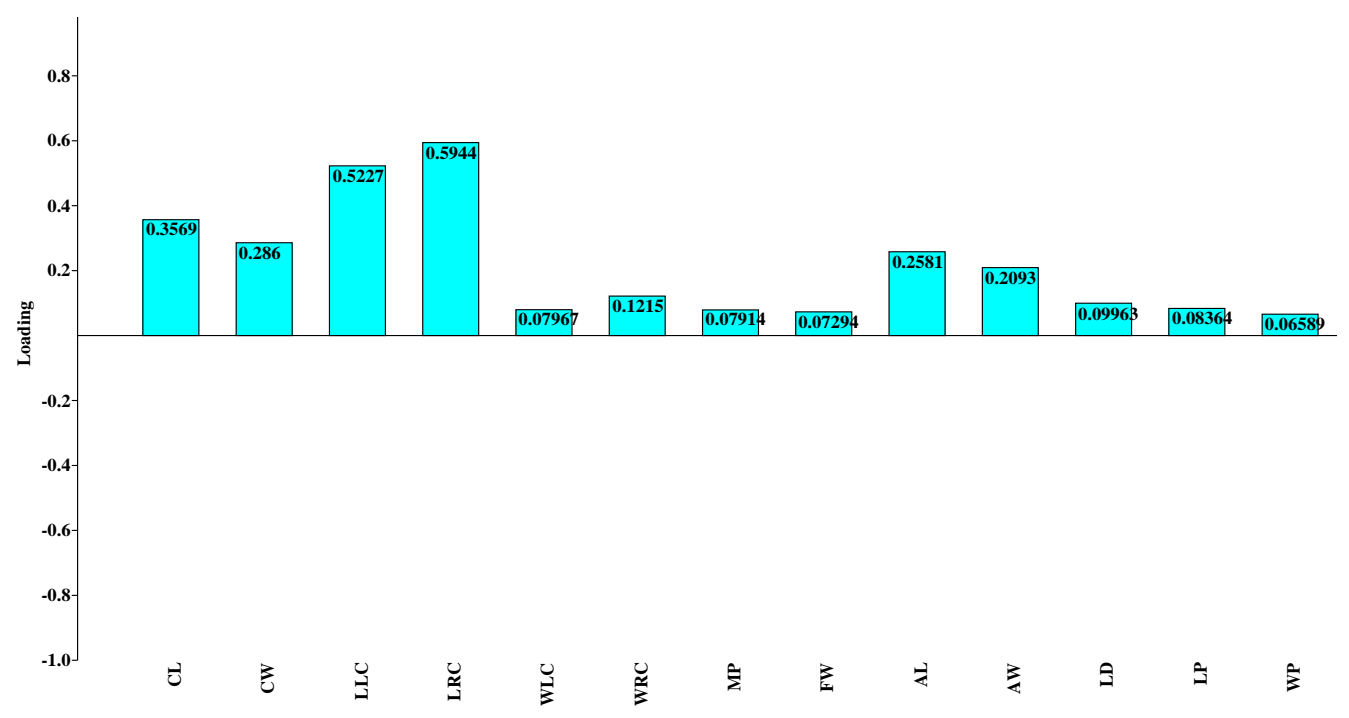

Figure 3: Loadings of the morphological characters of S. africanus from the three study locations on PC 1 of the principal component analysis

$\mathrm{CW}=$ Carapace width, $\mathrm{CL}=$ Carapace length, $\mathrm{LLC}=$ Length of Left chela, $\mathrm{LRC}=$ Length of right chela, WLC $=$ Width of left chela, WRC $=$ Width of right chela, MP $=$ Length of Mandibular palp, FW= Frontal width, $\mathrm{AL}=$ Abdominal length, $\mathrm{AW}=$ Abdominal width, $\mathrm{LD}=$ Length of dactyl, $\mathrm{LP}=\mathrm{Length}$ of palm, WP= Width of palm. 


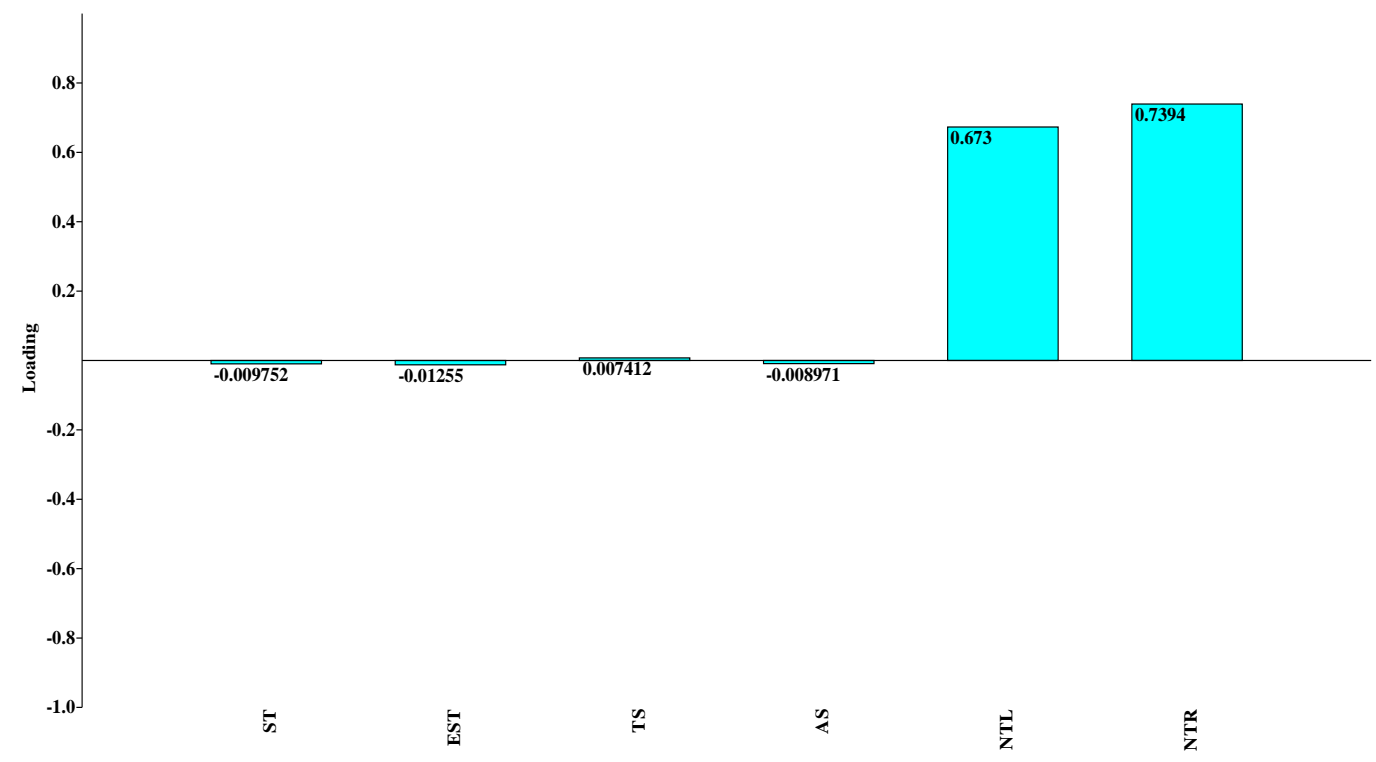

Figure 4: Variations of the meristic characters of $S$. africanus from the three study locations and their loadings on PC 1 of the principal component analysis

$\mathrm{ST}=$ Number of sternum, EST $=$ Number of Episternite, $\mathrm{TS}=$ Number of Thoracic segment, $\mathrm{AS}=$ Number of abdominal segment, NTL $=$ Number of teeth on the left chela, NTR $=$ Number of teeth on the right chela.

\subsection{Canonical Variate analysis of $S$. africanus in the three study locations}

The Canonical Variate Analysis (CVA) of the morphological characters of S. africanus from the three study locations is shown in Figure 5. Overlapping of the clusters was observed from the three study locations. The overlapping clusters might have implied that the samples are from the same ancestral population origin.

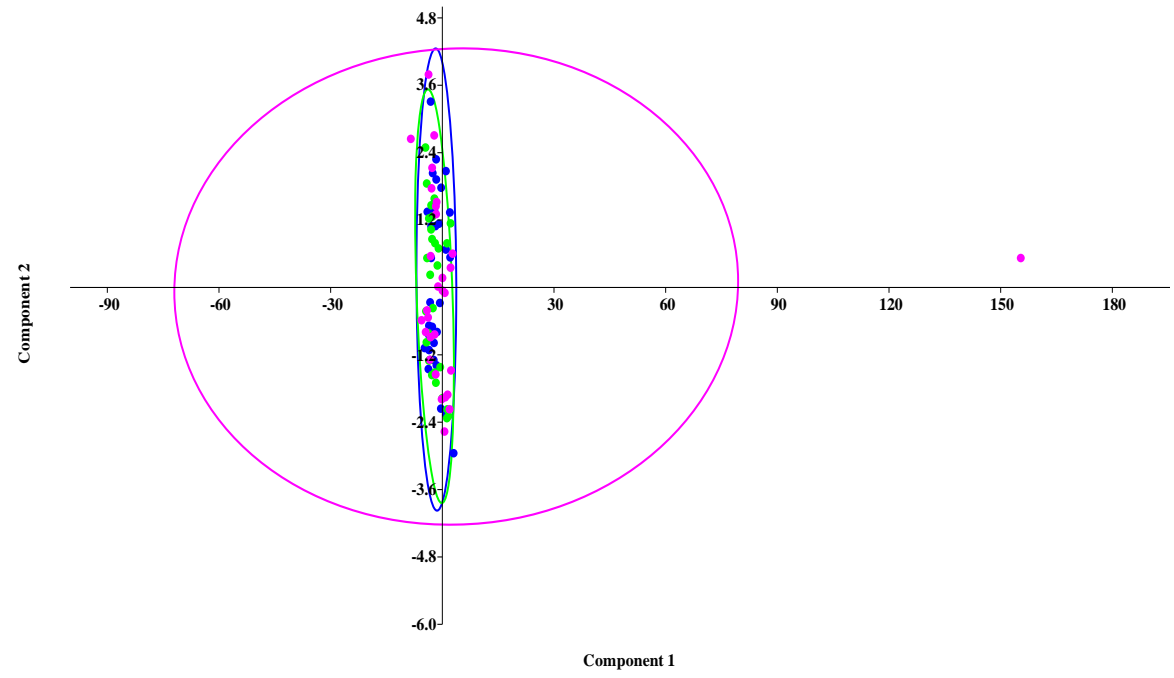

Figure 5: Canonical Variate Analysis of morphological characteristics of $S$. africanus in the three study locations on PC. OAla River Ogbese River O Owena River 


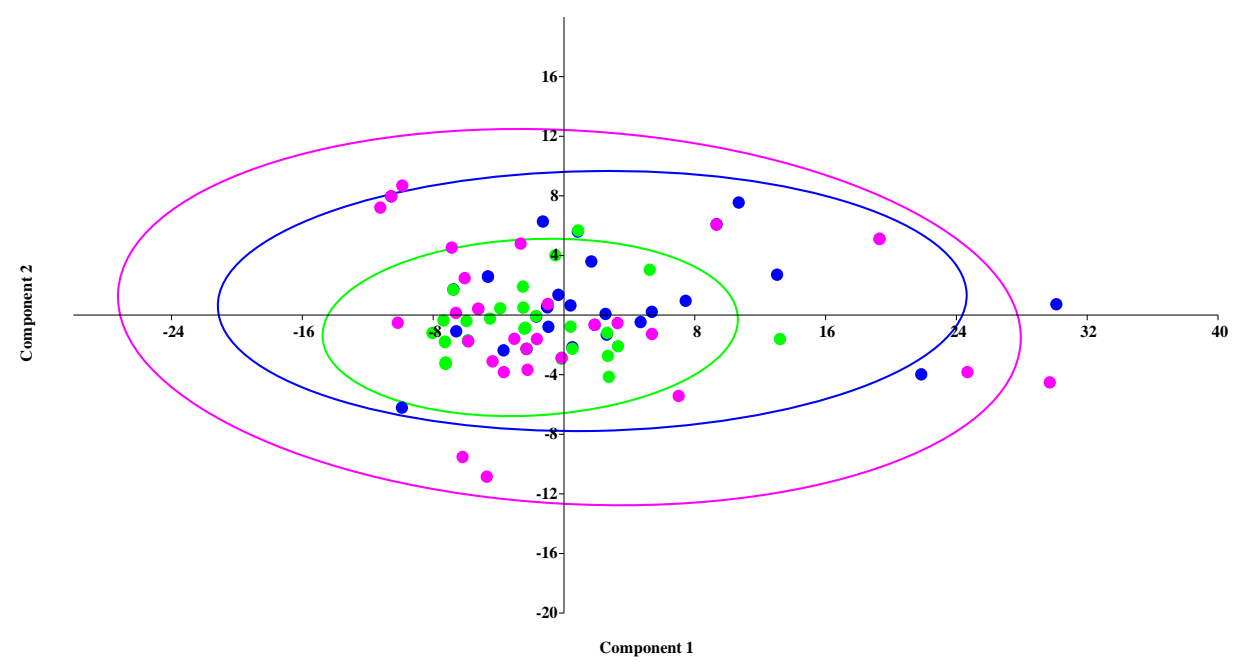

Figure 6: Canonical Variate Analysis of the meristic characters of S. africanus in the three study locations. Ala River 点 Ogbese River Owena River

\section{DISCUSSION}

\subsection{Morphological variations in S. africanus}

The present study reveals the growth pattern of $S$. africanus in three different populations in South-west, Nigeria. The relationship between the carapace length and weight of crabs are often used to calculate standing stock biomass, condition indices, analysis of ontogenic changes and many other aspects of crustacean population dynamics (Atar and Secer, 2003; Bello-Olusoji et al., 2009). They can also be used for management of crab population and also to estimate the recovery of edible meat from crabs of various sizes (Khan and Mustaqueem, 2013).

Studies of relative growth in crustaceans allow to define the type of allometry in the growth of different body parts, such as chelae, locomotor appendages, abdomen and pleopods, and to relate them to their specific functions (Ribeiro et al., 2013). The allometric relationships are powerful tools used by taxonomists and ecologists in the analysis of intraspecific and interspecific variation among different populations and to estimate the average size at sexual maturity, also related to environmental conditions (Costa \& Soares-Gomes, 2008). The growth pattern in morphometric studies is represented by the growth co-efficient $(b)$ value. The ' $b$ ' values have significant impact on the well-being of fishes (including shell fish) and fishery (Lawson and Oloko, 2013).

The mean weights of the crabs recorded in this study for the three locations is similar to the work of Aderinola et. al., (2013) on C. pallidus. However, Bello-Olusoji et al.,(2009) reported a slight difference in the weight of $S$. africanus in South-west Nigeria. The difference in the results could be due to the season of collection of the sample. Result of the carapace length in the three locations is similar to result obtained by Bello-Olusoji et al., (2009) and Aderinola et al., (2013). The growth patterns of $S$. africanus in the study locations exhibit a negative allometry $(b<3)$ when comparing the study locations. This result is supported by the findings of 
Lawal-Are and Kusemiju, (2000) on Callinectes amnicola on the Badagry lagoon. The result of the study is also similar to the works of Olugbenga and Oloko (2013) from Yewa River, South-west, Nigeria. The $b$ value reported by Okon and Sikoki, (2014) on the African fiddler crab (Uca tangeri) also supports the result for the $b$ value recorded in this present study. Similar results were recorded by Thirunavukkarasu and Shanmugam (2011), on the mud crab Scylla tranquebarica. The $b$ value of the female crabs in Ogbese River is similar to the works of Cumberlidge, (1991) on S. kagaroensis. The growth pattern observed in S. africanus in this study is similar to the result recorded by Ribeiro et al., (2013) on Sesarma rectum. However, the result of the $b$ value reported in this study is in contrast with the findings of BelloOlusoji et al., (2009) who reported an isometric growth $(b=3)$ on $S$. africanus in South-west Nigeria. The difference might be as a result of different collection points and time of collection. Also, Sparre and Venema (1992) link this variation to environmental variables like temperature, salinity, food (quantity and quality), sex and maturity stage

From this study, the Length-weight relationship showed variations in the morphological parameters of S. africanus in the three populations. This was confirmed by the loading plots from the Principal Component (PC). The results show that, Length of left chelae (LLC) and the Length of right chelae (LRC) contributed to the variations in the morphological parameters of S. africanus. The continuous use of the chelae for defense, predation and feeding might be the reason for the morphological variations of $S$. africanus in the studied populations. Habitat destruction as a result of human activities might have exposed this animal to predation, and to their prey, hence the difference in Length of left chelae (LLC) and the Length of right chelae (LRC)

\subsection{Condition factor of $S$. africanus}

The general condition of a fish gives an indication of the well-being of the fish. Such conditions help in classifying a fish stock or population as either poor, good or excellent. Condition factor is a helpful measurement tool to assess variations between fish population in comparison to weight and length (Luckhoff, 2005). It varies from species to species (Lawson and Oloko, 2013).

The condition factor $(K)$ of a fish population may be influenced by various factors such as availability of food (quality and quantity), seasonal variations, sex and stage of maturity of the fish, adaptation to environment, gonadal conditions/development of the fish (King, 1995), temperature, and salinity.

According to Moradinasab et al., (2012), high condition factor values indicate favourable environmental conditions such as habitat and availability of food. This fact is relevant to this work since the condition factor ranged from 32.99 to 41.52 for male crabs, 33.27 to 42.12 for female crabs in the study locations, and 33.17 to 41.99 for the populations of each of the study locations. The result of the condition factor obtained from Ala River is similar to the findings of Bello-olusoji et al., (2009) on the same species of crab. In relation to the sexes, the female crabs in Ogbese River have the best condition in terms of their well-being. The reason for the female being the healthier is due to their gonadal maturity stages and/or some of the female may be gravied. In terms of the study locations, S. africanus collected from Ogbese River are 
the healthiest. This result is supported by the works of Olalekan and Lawal-are (2013) on the condition factor of Cardiosoma guanhumi and Cardiosoma armatum from a mangrove swamp ecosystem in Lagos, Nigeria. High $K$ value is an assumption of high feeding intensity and gradual increase in accumulated fat that also suggests preparation for a new reproductive period (Okon and Sikoki, 2014).

The crabs in Ogbese River seem to be healthier than the other two populations. The reason for this is due to the farming activities carried out in the environment. These activities have made the environment rich, hence, the abundance of food substances.

The regression coefficient showed that there is a strong correlation (relationship) between the carapace length and weight of the female S. africanus (51\% and $71 \%$ for Ala and Owena River). The values of the correlation factor for the male $S$. africanus in the three study locations are weak $(36 \%, 16 \%$ and $0 \%)$ for Ala, Ogbese and Owena Rivers respectively. For the combined sexes, the strongest correlation co-efficient was seen in Owena River.

The arrangement of the clusters and the characters outside the clusters revealed that the crabs belong to the same ancestral origin, but some changes have taken place in them to aid their survival and to be more adaptability, given room for genetic variability. (Austin 2000) reported that genetic variability can be affected by climate change, natural disasters and diseases. Genetic diversity has been reported to have a correlation with the potential for adaptation to changing environmental conditions (Lynch, 1985). This variation noticed might be a mean of adaptation of crab in the face of several factors reported by Austin, (2000).

In characterization of crab $S$. africanus, this study revealed that Length of Right Chelae (LRC), the Length of left chelae (LLC), Carapace Length (CL), Carapace width (CW) and the Abdominal Length (AL) are morphometrics characters that could be adopted for characterization of fresh water crab, while Number of teeth on the left chela (NTL) and Number of teeth on the right chela (NTR) for meristic characters.

\section{REFERENCES}

Aderinola, O.; Adeboyejo, A.; Clarke, E. and Kusemiju, V. (2013). A study of length-weight relationship and condition factor of West African blue crab (Callinectes pallidus) from Ojo Creek, Lagos, Nigeria. American Journal of Research Communication, 1(3): 102-114

Atar, H.H. and Secer, S. (2003). Width/Length Relationships of blue crab (Callinectes sapidus, Rathbun, 1896) Population living in Beymelek Lagoon Lake. Turk. J. Vet. Anim. Sci., 27:443-447. DOI: 10.3923/pjbs.2006.1460.1464

Austin, B. (2000). Perspective: Sex, Recombination, and the efficacy of selection- Was Weismann Right? Evolution, 54(2):337-351 http://dx.doi.org/10.11646/zootaxa.4242.1.8

Bagenal, T.B. and Tesch, F.W. (1978). Age and growth. In: T. Begenal (Ed.), Methods for assessment of fish production in fresh waters, 3rd Edn. IBP Handbook No. 3, Blackwell Science Publications, Oxford: 101- 136

Bello-Olusoji, O. A; Anifowose, O. J. and Sodamola, M. Y. (2009). Length-Weight Relationships, Condition Factor and Fecundity of the West Africa Freshwater Crab, 
Sudanonautes africanus (Milne-Edwards 1883), in Western Nigeria West African Journal of Applied Ecology, 16: 65 - 74. http://dx.doi.org/10.4314/wajae. v16i1.55869

Chu, K.H.; Tsang, L.M.; Ma, K.Y.; Chan, T.Y. and Ng, P.K.L. (2002). Decapod phylogeny: What can Protein-Coding Genes tell us? pp $15-25$.

Costa, T. and Soares-Gomes, A. S. (2008). Relative growth of the fiddler crab Uca rapax (Smith) (Crustacea: Decapoda: Ocypodidae) in a tropical lagoon (Itaipu), Southeast Brazil. Pan-Am. J. Aquat. Sci., 3(2): 94- 100. http://dx.doi.org/10.1.1.532.2666.

Cumberlidge, N. (1991). Sudanonautes kagoroensis, a new species of freshwater crab (Decapoda: Potamoidea: Potamonautidae) from Nigeria. Canadian Journal of Zoology 69(7):1938-1944

Cumberlidge, N.; Ng, P.K.L.; Yeo, D.C.J.; Magalhaes, C.; Campos, M.R.; Alvarez, F.; Naruse, T.; Daniels, S.R.; Esser, L.J.; Attipoe, F.Y.K.; Clotilde-Ba, F.-L.; Darwall, W.; Mclvor, A.; Ram, M. and Collen, B. (2009). Freshwater crabs and the biodiversity crisis: importance, threats, status, and conservation challenges. Biological Conservation, 142:1665-1673.

Elewa, M. T. and Ashraf, F. (2004). Morphometrics- Application in Biology and Paleontology. Springer Science and Business media ISBN 3-540 - $21429-1$.

Elliott N. G.; Haskard, K. Koslow, J. A. (1995). Morphometric analysis of orange roughy (Hoplostethus atlanticus) off the continental slope of southern Australia. Journal of Fish Biology, 46, 202-220.

Gayanilo, F.C. and Pauly, D. (1997). FAO ICLARM Stock Assessment Tools (FiSAT). References manual, FAO computerized information series (Fisheries) (8): 262.

Khan, M. A. and Mustaqueem, J. (2013). Carapace width-wieght relationship of mud Scylla serrata (Forskal.1775) from Arachi coat. Can Journal of Pure and Applied Science. 7(2):2381-2386. http://dx.doi.org/10.21013/jas.v5.n1.p5

King, M. (1995). Fisheries Biology, Assessment and Management. Fishing News Books, Oxford, England. 1: 25 - 43

Lawal-Are, A.O. and Kusemiju, K. (2000). Size composition, growth pattern and feeding habits of the blue crab, Callinectes amicola (drocheburne). In: Badagry lagoon, Nigeria. J. Sci. Res. Dev., 4: 117-126.

Lawson, E. O. and Oloko, R.T. (2013). Growth patterns, Sex ratios and Fecundity estimates in Blue Crab (Callinectesamnicola) from Yewa River, Southwest Nigeria. 215 - 218pp

Luckhoff, P. D. (2005). Application of the condition factor in the production of Sharp tooth catfish, Clarias gariepinus. A dissertation downloaded at www.googlescholar.org on June 16, 2017.

Lynch, M. (1985). Spontaneous mutations for life history characters in an obligate parthenogen. Evolution, 39: 804-818. http://dx.doi.org/ 10.1111/j.1558-5646. 1985.tb00422. x.

Moradinasab, G.H.; Raeisi, H.; Paighambari, S.Y.; Ghorbani, R. and Bibak, Z., (2012). Length-weight relationships, relative condition factor and relative weight of three fish species from beach seine fishing grounds in Iranian coastal waters of Caspian Sea. Academic Journals 7: 1809-1812. http://dx.doi.org/10.5897/SRE12.255 
Mvogo-Ndongo, P.A.; Schubart, C.D.; Rintelen, V.T.; Tamesse, J.L. and Cumberlidge, N. (2017). Morphological and molecular evidence for a new species of freshwater crab of the genus Sudanonautes Bott, 1955 (Brachyura: Potamoidea: Potamonautidae) from Cameroon, with notes on its ecology. Zootaxa 4242 (1): 161-173.

Okon, E. and Sikoki, F. D. (2014). Length-weight Relationship, condition factor of the West African Fiddler crab (Uca tangeri) in Mbo River, Akwa Ibom State, Nigeria. Journal of Natural Science Research 4(14): 33 - 41.

Olalekan, E. I. and Lawal-Are A. O. (2013). Comparative study of Condition factor, Stomach Analysis and Some Aspects of reproductive biology of two Land Crabs: Cardiosoma armatum (Herklots, 1851) and Cardiosoma guanhumi (Latreille, 1825) from a Mangrove Swamp Ecosystem, Lagos - Nigeria. J Marine Sci Res Dev 4:143pp. http://dx.doi.org/10.4172/2155-9910.1000143

Olugbenga E. and Oloko, L.R.T. (2012). Growth patterns, sex ratio and fecundity estimates in blue crab (Callinectes amnicola) from Yewa River, Southwest Nigeria. Advances in life and Technology 7:24 - 34 .

Oyewole, O. O.; Aboderin, O. O.; Aluko, O. J. and Adeyemo, J. O. (2013). Length-Weight Relationship of Freshwater Mussel (Etheria Elliptica) From River Ogbese, Nigeria. Nigerian Journal of Fisheries 10 (1 \& 2): 627 - 631

Ribeiro, F.B., Cascon, H. M. and Bezerra, L.E.A. (2013). Morphometric sexual maturity and allometric growth of the crab Sesarma rectum Randall, 1840 (Crustacea: Sesarmidae) in an impacted tropical mangrove in northeast Brazil. Lat. A m. J. Aquat. Res., 41(2): 361-368, 2013. http://dx.doi.org/10.3856/vol41-issue2-fulltext-15

Sodamola, M. O.; Bello-Olusoji, O. A. and Adejola, Y.A., (2010). Gonadal Developments of West African Freshwater Crab Sudanonautes africanus, (Miline-Edwards, 1869) on the Banks of Asejire Reservoir, Nigeria Journal of Biology, Agriculture and Healthcare 6 (19): 2016 ISSN 2224-3208 (Paper) ISSN 2225-093X (Online) www.iiste.org

Sparre, P. and Venema, S.C. (1992). Introduction to tropical fish stock assessment. Part 1. Manual. FAO Fisheries Technical Paper No. 306. 1, Rev. 1. Rome, FAO. 1992, 376 p

Thirunavukkarasu, N. and Shanmugam, A. (2011). Length-Weight and Width-Weight Relationships of Mud Crab Scylla tranquebarica (Fabricius, 1798). European J. Appl. Sci., 3(2): 67-70. http://dx.doi.org/10.13057/biodiv/d180405

Turan, C.; Erguden, D.; Turan, F. and Guriek, M. (2004). Genetic and morphology structure of Liza abu (Heckel, 1843) populations from the Rivrs Orontes, Euphrates and Tigris. Turkishv vetenary and animal Science. 28: 729- 734.

Turan, C. (2004). Stock identification of Mediterranean horse mackerel (Trachurus mediterraneus) using morphometric and meristic characters. ICES Journal of Marine Science. 61(5): 774-781. http://dx.doi.org/10.1016/j.icesjms.2004.05.001. 